\title{
Kayoman youth ecoliteracy movement: from tradition to education
}

\author{
I Ketut Margi ${ }^{1}$, Luh Putu Sendratari ${ }^{2}$ \\ \{ketut.margi@yahoo.co.id $\left.{ }^{1}\right\}$ \\ Universitas Pendidikan Ganesha, Indonesia ${ }^{12}$
}

\begin{abstract}
A Nature Lover Movement called Kayoman Pedawa has emerged in Pedawa Village, which carried out an ecoliteracy-oriented movement to rescue water. The goals of this study are to (1) clarify the factors behind the ecoliteracy-oriented water rescue movement of Kayoman Pedawa; (2) define and explain the movement strategy of Kayoman Pedawa in ecoliteracy-oriented water rescue action. The Discontent Theory by Alberto Melucci and the theory of McCarthy's Resource Mobilization Structure served as the basis for understanding the context of the strategy for the emergence and movement. With the stage of purposively identifying informants, a qualitative approach is used; determination of primary and secondary data sources; methods of data collection by evaluation, interviews, and documentation; data analysis was conducted descriptively qualitatively through stages of reduction, display and conclusion. In Pedawa, there are three variables found behind Kayoman Pedawa doing the water source rescue movements, namely (1) Concern factor for the state of water sources; (2) Factor of ideological similarity; (3) Sociocultural factor - water as a traditional and cultural resources vehicle. The movement's strategy is to involve the resources of social organizations. The efforts to be made include strengthening the capacity and mobilization of organizational resources, both human resources and material resources (infrastructure), and creating networks of stakeholders inside and outside Pedawa Village.
\end{abstract}

Keywords: Social Movement; Ecoliteracy; Identity Reconstruction; Inculturation; Networking; Capacity Building

\section{Introduction}

Bali is not as beautiful as the tales of Indolog. Even Bali is still facing different problems. There are three key problems that are threatening Bali's sustainability, according to Tisna [1], the three main problems include (1) environmental - the competition increasement for the use of natural resources especially the water and the land, and the harmful acts to the environment; (2) social - the unequal distribution of economic income and cultural dislocation or strain on Balinese society, social order and traditional; (3) managerial - the weak management system and limited funds for development [2].

In the midst of concerns about the environmental problems in Bali, Nature Lovers that is called Nature Lovers of Pedawa/Kayoman Pedawa (hereafter Kayoman Pedawa) appeared precisely in the village of Pedawa that conducts the ecoliteracy-oriented water rescue movement. The movement focuses on local knowledge and wisdom that the Pedawa community has. 
The movement of Kayoman Pedawa invited numerous responses from the group. Some are positive, some are the opposite. Kayoman Pedawa also faces some obstacles and difficulties in four years of the journey, since its establishment in 2016. However, by discovering the local knowledge and wisdom that is embedded the culture, Kayoman Pedawa still exists and is dedicated to building the village. Thus, it is certainly an interesting phenomenon to study.

In the water rescue movement, the examination of local wisdom is intended for relevant scholarly research about how local communities develop their environmental awareness. In addition, it also aims at ensuring the blend of modern and traditional information comprehension. It needs to be done, given that the word Indology was documented in the history of Indonesia. In comparison to the Dutch and Western Europeans, the Indies and its people are depicted as inferior from an Indological point of view. From the western perspective, the picture of an inferior, less knowledgeable East seems irrelevant to understand the society's life. Amid the indications of claims to traditional knowledge, the emergence of the philosophy underlying the indigenous knowledge became relevant, thereby triggering an academic debate on the defense of traditional knowledge [3].

The questions of this research are based on such rationales: (1) Why did Kayoman Pedawa conduct the Ecoliteracy-oriented movement for water rescue? ; (2) What is the approach of the ecoliteracy-oriented water rescue action movement?

To understand the emergence and strategy of Kayoman Pedawa in making its movements, Alberto Melucci's Frustration Theory and McCarthy's Resource Mobilization Structure theory were used.

One part of the philosophy of a modern social movement is the mobilization of human capital theory. The emergence of new social movements is characterized by the increasing range of actors in social movements such as students/professionals, women and no longer being the portfolios of workers and farmers, as well as the issues to be accomplished such as human rights, democratization, women, the environment, inequality, which turned the study of social movements from centralized into spreading on different discipline centers [4].

In addition, Edward and McCarthy [4] claimed that human resources are a category that includes actors and their experience and knowledge. It is all about people who have certain talents, abilities, and experiences that meet the needs of a social movement. In order to get funding and participants, a campaign should be able to organize its actors.

\section{Method}

This study was conducted using a qualitative descriptive technique in Pedawa Village, Banjar District, Buleleng, Bali. Data sources from primary and secondary sources were collected. Primary sources were obtained from the community leaders (Mr. Wayan Sukrata); Mr. Wayan Sadnyana and Kayoman group: Putu Yuli Supriyadnya; Made Suisen; while secondary sources came from research results, text books, social media, and the internet. Data validity was carried out by triangulating activities through data collection, data reduction, data presentation, and conclusion drawing.

The primary data was collected from the results of filling out the questionnaire. Analytical induction techniques are used to analyze research data. Analytical induction, which is one of the typical data analysis techniques, is carried out with a stringent process in sequence to study the phenomenon under study [5]. 


\section{Result and Discussion}

\section{Kayoman Pedawa's Background to Water Source Rescue Movement}

Based on the data field analysis and theoretical studies, it was found that there were several variables that triggered Kayoman Pedawa to conduct the water source rescue movements. Such influences are as follows.

\section{Anxiety over Water Source Condition}

In Pedawa, the campaign to conserve water supplies could not be isolated from the habits of a group of young men who were inclined to go for a walk in the forest. Sekeha Demen Ngelindengin Halas Pedawa (SDNHP) is the way they address themselves (Made Suisen, 45 years old, interview, November 5, 2020).

The youths felt happy and concerned at the same time. The happiness emerged because their village had many water sources. The concern was triggered by the smaller water discharge, especially during the dry season. This condition was increasingly felt after 2007. The smaller water discharge seemed to be closely related to changes in the Pedawa ecosystem.

The Pedawa area was dominated by palm plants (in Balinese, jake) before the 19th century. The palm tree or the enau tree has the advantage of being a water storage. Information that one adult palm tree can store 150 to 200 liters of water was obtained from agricultural studies. Certainly, if one region is packed with palm plants, the freshness and abundance of water will easily be found. The main source of income of the Pedawa community is from palm trees, according to the story of the elders in Pedawa (the note of I Gede Widja, 2007). At that time, people depended on the production of palm sugar and the Kolang-kaling fruit [6]. However, since the Pedawa region was transformed into a coffee plantation area in the 19th century and early 20th century, the situation changed. At the time, the Dutch government suggested that the population plant export commodities, as it was highly sold on the world market. In addition, it was often motivated by political considerations, namely as an attempt to control mountainous areas, which might be used by small businessmen who opposed the Dutch, such as in the case of Banjar war [6].

The introduction of export commodity crops, such as cloves, coffee to the Pedawa people, decrease the number of palm trees because they were cut down and replaced by new, more promising plants, namely cloves and coffee. The presence of gradually reduced palm trees was linked to the state of water discharge in Pedawa Village. The characteristic of clove plants, which literally need water, confirmed this phenomenon. In other words, cloves require more water than other plants. It was contradicting plants of Enau/aren that have a water storage function. One of the causes of Pedawa young children's anxiety is the analysis of changes in the Pedawa ecosystem, especially the small water discharge.

Furthermore, another cause of Pedawa youth anxiety is the increase of rare ceremonial plants that emerged around the water source. In the ritual event in Desa Adat, there are several plants required, such as Lateng Ngiu as a complement to the wedding ceremony; banyan leaves for completeness of penjor and decoration of pelinggih; bamboo for the production of kemulan nganten, penjor, katik sate, klakat, etc. For the completeness of Banten Balun, palm leaves are needed. If the plant is not maintained, it is imagined that social and environmental disasters would happen.

The need for upakara services, as well as the marginalized ceremonial plants due to the domination of plants for the modern market, on the other hand, became the source of some young people's anxiety in Pedawa. 
These problems lower their awareness of their responsibility as ritual practitioners. Traditionally, at the moment of the ngusaba village ceremony, sekeha teruna has the responsibility to carry the banyan leaves to the village temple. In an effort to answer this anxiety, one of the youth leaders of Pedawa Village, namely Mr. Wayan Sadnyana, suggested that groups who like to go around the forest should be formalized as an organization so that access to activities can be expanded and recognized by the community.

The Kayoman Pedawa group, which until now consists of 30 individuals composed of active and inactive members, was born on that basis. According to Made Suisen (45 years old), the initial name of this group is "Lestari Alamku, Indah Desaku" whose predecessor began with Sekaa Demen Ngelindengin Halas Pedawa (SDNHP). It was called Kayoman Pedawa after being created legally, which means guided and safe, in Sanskrit. The motto of Kayoman Pedawa is "Ngastiti Ngayomin Desa" (praying, protecting the village). Thus, young people have the goal of preserving the village. To get rid of anxiety, this slogan becomes their spirit.

It can be said that anxiety is a significant factor behind Kayoman Pedawa's water source rescue movement in Pedawa Village, based on the description above. It is in line with the theory of discontent that states the feelings of dissatisfaction [7] are the origin of social movements. This result is also in line with the research by Suwarno [8] on the Rumbling Movement, which was driven by concerns about environmental harm to the water areas in Muncar District.

\section{Water as Cultural Asset and Ritual Facility}

Water is an utter necessity for humans. Water is used for several purposes, including household use; recreational areas; industrial (large, medium and small) purposes; trade; farms. The same also goes for the people of Pedawa Village. Water is used for the daily household and household industries especially cooking, bathing, and washing based on the results of the interview. Water is also used for agriculture and livestock, in addition to household purposes. Finally, the important thing is that the people of Pedawa use water as a ceremonial weapon. There are many traditions whose implementation is very dependent on the presence of water, including the Ngeyehin Karang tradition and the Ngangkid tradition. One of the rituals that are very sacred and have a direct dependency on water especially the water flowing in Tukad Pengangkidan, is the Ngangkid ritual. This practice of Ngangkid is almost identical to the Ngaben Ceremony in Bali generally. Based on the beliefs of the local people, this tradition is a ceremony of pengangkidan spirit of Pedawa people who are serving sentences in a sacred place, called Tukad Pengangkidan. Here is the location of the Ngangkid ceremony. 


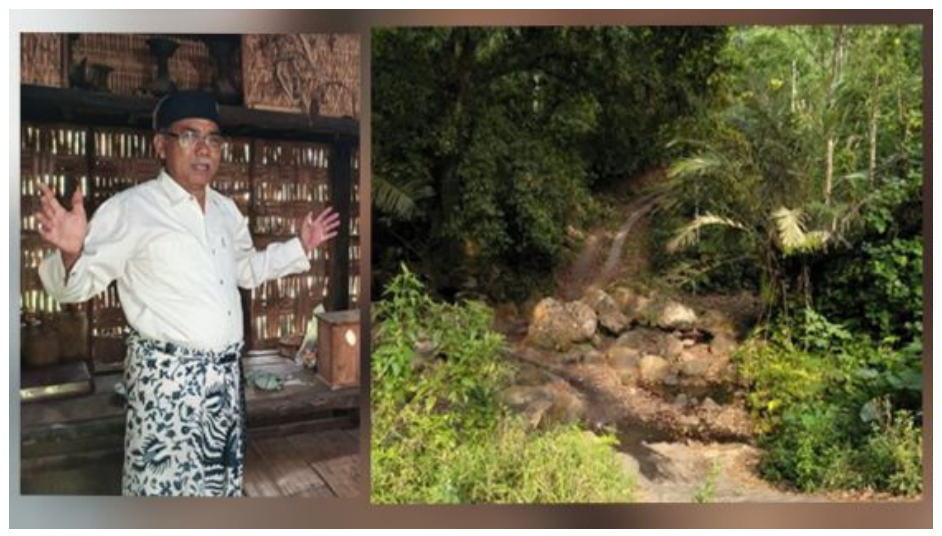

Source: (Dian Suryantini/Bali Express documentation).

Figure 1. Tukad Pangangkidan in Pedawa Village, Banjar District, Buleleng, is the location of Ngangkid Roh ritual for local people. Panglingsir Pedawa Village, Wayan Sukrata.

The need for water for the purposes of all of the above activities was met from kayoan (water sources) and rivers that flow in Pedawa Village. It shows how important water is for the Pedawa people. It can be said that water is the source of life for the Pedawa people. The need for water prompted the youth who joined Kayoman Pedawa to take the initiative in their village to save the flowing water. Thus, a group of young men who ultimately took the social action/collective action, namely the rescue of water supplies in their village, had a shared ideology. This finding is in line with the results of Badawi [9] on the rise, against the context of ideological parallels, of the Disaster Response Social Movement.

\section{Movement Strategy}

There are several techniques carried out in the execution of the action, based on the result of the interview. The first is to improve the capacity building of facilities and organizations. They all agree that to achieve the goal, it must have a legal organization and be trusted by the community in accordance with the motto of ngastiti ayuning village. First, increase the organization's capacity. It can be seen from the changing status of Sekaa Demen Ngelindengin Halas Pedawa (SDNHP) to "Lestari Alamku, Indah Desaku" and on December 6, 2016, the status was legalized to Kayoman Pedawa. The next effort is to create the organizational completeness (organizational structure), to create the association articles and bylaws, as well as the organization logo/symbol. Here is the logo/symbol for Kayoman Pedawa. In the logo/symbol, the motto, mission, and goals of Kayoman Pedawa, namely Ngastiti Ayuning Desa, are written.

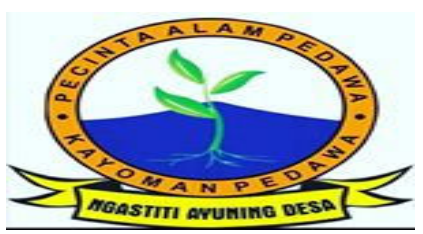

Source: Putu Yuli Supradnyana documentation, 2016. 
By making a secretariat as the place to run the organizational activities, such as internal meetings, coaching and training places, and receiving visitors from outside of Pedawa Village, infrastructure capacity can be improved. In addition, it is used to save various seed donations from the Environment Agency in the form of majegau, banyan, soursop, cempaka, sapodilla, sember and areca trees, as well as other seeds which are endemic to Pedawa, which the members strive for independently, such as bunut, lateng, ampelan and kolang kaling fruits/ jake fruits. The secretariat is situated at Chairman Kayoman Pedawa's building (Putu Yuli Supradnyana).

The next approach is to create a social network or collaboration network (social networking). The effort is to mobilize human capital according to each member's capacity and skill. It is in line with the statement from Edward and McCarthy that human resources are a category in which actors and their knowledge and skills are included. It is all about people who have unique talents, abilities, and experiences that suit a social movement's needs.

Resource mobilization is not just in-there, but also external, reinforcing human resource capacity in developing networks with different organizations beyond Kayoman Pedawa. This move is carried out in the light of the holistic view of environmental issues, so it is important for other parties to support the activities of Kayoman Pedawa, such as the head of the village, the head of the environment and the local community. It is also essential, in addition, to establish the cooperation with outside parties. The Environment Department, the Mahima society, Minikino (short film workshop), and others are some of the parties invited to collaborate (Sadnyana, 45 years old, interview, November 5, 2020)

Environmental problems and the rescue of water supplies are not limited to the tree planting problems, not only upstream or systemic problems - the village government and supra villages, but also downstream problems or cultural problems or citizens' literacy problems. Therefore, it is important to add group perspectives on ecoliteration.

In order to form habitus on environmental awareness, the selected strategy is cultivation/inculturation. In Pedawa Village, the goal is elementary school children with the consideration of "it is easier to form character values in children than parents/elderly". Furthermore, Pedawa's future is their property and duty.

The goal and intent is to provide environmental literacy, or ecoliteracy as named by Capra. Education on environment with the participation of students in overcoming the ecological crises is very important because it can enhance the younger generation's environmental literacy skills [10] (Noya, 2013:118-119). In addition, it can reinvigorate the sensitivity of students to spatial planning [11] It is in line with Febriani's [10] findings, which notes that the advent of a literacy movement is intended to increase the literacy potential of the younger generation.

Efforts and methods taken are introducing the Pedawa environment by telling stories, making observations through walking through nature and water sources in Pedawa, and concrete actions in the form of planting trees around the river.

This model was selected because it is known to get students closer to the real world than by just providing the definition of environment as written in the book. Real learning through real experiences can also be used as a reflection tool for students to check directly between what is learned through books and reality. This kind of confirmation is important so that there are no misconceptions in learning.

The basic principle to be instilled is not only a successful formation of environmental groups, but also being able to "make love" to the environment. Thus, there is a value construction of environmental care and the value of responsibility in every activity carried out by Kayoman Pedawa. 
In order to achieve the points above, it is needed to revitalize the local wisdom that is hidden behind the tradition, such as the Ngangkid tradition, the ngeyehin karang tradition, and to know the Pedawa's ecosystem: the source of water and ceremonial plants and the value of living in the community. Knowledge, values, norms, beliefs and environmental ethics behind it are socialized to children, young people, and members of the community, to be used as guidelines for behavior and behavior in carrying out traditions and respecting nature. Thus, to safeguard local wisdom in the future, steps are needed: a) Strengthening community spirit b) Increasing understanding, awareness, concern, and community participation towards an environmentally wise society [12]. Internalization of ecological values contained in local wisdom can help generate human awareness in managing the natural environment so that it can form a good ecological attitude and can make a positive contribution to the preservation of the natural environment [13].

Publishing all events in the form of news in printed and electronic media, Facebook and Instagram is another crucial thing to do. Based on the interview's findings, it was not only intended to introduce Kayoman Pedawa to outside parties, but also to hide the curriculum, namely the reconstruction of identity. Through sociocultural practices, Kayoman Pedawa wanted to shift the derogatory stereotype and predicate/the marking of Pedawa, such as a negative society, fights addicted, bouncers. Published by Kayoman Pedawa via social media, the negative stereotype is expected to be turned into a positive direction. Furthermore, it is expected that there will be a change of attitude through the speech on social media: from "de kemu" (do not go there) to "lan kemu" (Let's go).

It can be said, based on the explanation above, the movement strategy is to include the resources of social organizations. In the meantime, efforts are being made to improve the capacity and mobilize the organizational capital, both human and material resources (infrastructure), as well as to establish the cooperation with stakeholders inside and outside the Pedawa Village. It is in line with the Theory of Social-Organizational Capital from Edward and McCarthy (in Snow et al. 2004) that describes the social organizations are deliberately formed purposely to achieve the movement's goals. Three elements, namely: infrastructure; social networks; and organizations, can be classified as social-organizational tools.

\section{Conclusion}

Based on the data, it can be inferred that in Pedawa village there are three factors behind Kayoman Pedawa's water source rescue movement, namely (1) concern/anxiety factor about the smaller discharge of water; (2) factors of ideological similarity; (3) water factor as a cultural asset and religious practice. The movement strategy is to involve social organizations. Meanwhile, efforts are made by increasing the capacity and mobilization of the organization, both human resources and material resources (infrastructure) as well as cooperation with stakeholders, both inside and outside Pedawa Village.

\section{ACKNOWLEDGEMENT}

Thanks are addressed to the Head of LP2M Undiksha and his staff; Mr. Wayan Sukrata; The chairman of Kayoman Pedawa (Putu Yuli Supradnyana) and members, Made Suisen, Made Sucita, Putu Mega Ulia Dani, Wayan Sadnyana's colleagues and family for all their support so that this research can run properly. 


\section{References}

[1] I. G. R. P. Tisna, “ The Loss of the Last Heaven. Nature-Culture and Economic Temptations (in Bahasa)," in Kritis, Bali dalam Dua Dunia. Potret Diri yang, Denpasar: MatameraBook, 2003.

[2] S. Hanneman, Geneology of Indonesian Social Science Power. From Dutch Colonialism to American Modernism (in Bahasa). Depok: Penerbit Buku Kepik Ungu., 2010.

[3] P. I. Christiawan, "Cultural Landscape: A Bridge Between Deforestation and Local Community?,” J. Landsc. Ecol., vol. 11, no. 2, pp. 77-87, 2018.

[4] A. D. Snow, The Blackwell Companion to Social Movement. United Kingdom: Blackwell Publishing, 2004.

[5] J. W. Creswell, Research design pendekatan kualitatif, kuantitatif dan mixed. Yogyakarta: Pustaka Pelajar, 2012.

[6] I. G. Widja, " Selected works of Pak Widja (in Bahasa)," J. Candra Sangkala, vol. 1, no. 9, pp. 1-10, 2007.

[7] D. Neyland, "Dismissed Content and Discontent: An Analysis of the Strategic Aspects of Actor-Network Theory," Sci. Technol. Hum. Values, vol. 31, no. 1, pp. 11-18, 2006.

[8] J. Suwarno, “ Muncarku rumahku movement and resource mobilization strategy in environmental saving social movement (in Bahasa)," J. Pemikir. Sosiol., vol. 3, no. 2, pp. 1-10, 2016.

[9] I. M. Badawi, “ Disaster Response Social Movement (Case Study of Social Movement Patterns for Sibat Group, MTB and GKJW Disaster Embankment in Sitiarjo Village) (in Bahasa)," J. Mhs. Sosiol., vol. 1, no. 3, pp. 1-10, 2015.

[10]L. Febriani, “ Resource Mobilization in the Literacy Movement (in Bahasa)," J. Soc., vol. 5, no. 1, pp. 1-10, 2017.

[11] M. M. Masud, A. M. Aldakhil, A. A. Nassani, and M. N. Azam, "Community-based ecotourism management for sustainable development of marine protected areas in Malaysia," Ocean Coast. Manag., vol. 136, pp. 104-112, 2017, doi: 10.1016/j.ocecoaman.2016.11.023.

[12] Siswadi, Tukiman Taruna, Hartuti Purnaweni. 2011. "Local Wisdom in Preserving Springs" (Case Study in Purwogondo Village, Boja District, Kendal Regency). Journal of Environmental Science Volume 9, Issue 2: 63-68 2011. ISSN 1829-8907

[13] Erna Mena Niman. 2019. "Local Wisdom and Efforts to Preserve the Natural Environment". Missio Education and Culture Journal, Volume 11, Number 1, January 2019, p. $1-178$ 